\title{
Effect of Globalization on the Operational Performance: A Survey on SMEs in the Turkish Electric Industry
}

\author{
M. Şengül ${ }^{1}$, L. Alpkan ${ }^{2} \&$ E. Eren ${ }^{3}$ \\ ${ }^{1}$ Department of Industrial Engineering, Nişantaşı University, İstanbul, Turkey \\ ${ }^{2}$ Department of Business Administration, Istanbul Technical University, İstanbul, Turkey \\ ${ }^{3}$ Department of Business Administration, Okan University, İstanbul, Turkey \\ Correspondence: M. Şengül, Department of Industrial Engineering, Nişantaşi University, İstanbul, Turkey. \\ E-mail: mehmet.sengul@nisantasi.edu.tr
}

Received: May 14, 2015

Accepted: June 1, 2015

Online Published: June 25, 2015

doi:10.5539/ibr.v8n7p57

URL: http://dx.doi.org/10.5539/ibr.v8n7p57

\begin{abstract}
The effects of globalization on the operations of the enterprises are inevitable. Especially SMEs in developing countries have been highly affected by the competitive environment which has been intensified in parallel with the recent trends of globalization. For this reason, it is important to consider the factors affecting/improving the operational performance of SMEs when adapting themselves to globalization. Therefore this subject has been studied in this article. Data obtained through a survey on SMEs in a developing country, Turkey, reveal the effects of globalization on the operational performances. Findings show that different aspects of globalization such as competitive intensity, technological change, cost pressure, and new opportunities, affect different aspect of operational performance, namely quality improvement, cost reduction, flexibility, speed of delivery. Managerial and further research implications are forwarded.
\end{abstract}

Keywords: globalization, electric industry, operational performance

\section{Introduction}

After 1980s, the fundamentals of globalization may be regarded as the increasing speed of innovations and changes in especially electronics, communications and information-processing technologies; the liberalization of international trade in goods and capital markets; and liberalization of politics (İzmirlioğlu, 2000). Many developing countries including Turkey entered to the liberalization process with the lead of globalization. Turkey which had largely become open to global competition and liberalization since 1980s, made a Customs Union agreement with the EU in 1990s. Furthermore, Turkey has, as a member of the World Trade Organization, accepted the requirements of global competition.

SMEs firstly suffered from the global competition they faced, but then those SMEs which could be able to adapt and survive, succeeded to benefit from the opportunities worldwide. Under the intensive competitive environment created by globalization, SMEs undertake a crucial function in point of the national economies' development and protection. In the developing countries such as Turkey, SMEs have a considerably effective role in the development process of national economies and the protection against the negative effects of the global competition especially based on their employment facilities and their flexible structure reacting rapidly to environmental changes (İraz, 2005).

This study deals with the effects of globalization on the operational performance of SMEs in a developing country Turkey after the decades of liberalization and globalization. The following chapter begins with a discussion of the effects of globalization based on the recent literature. After that, the aspects of globalization and its effects on operational performance are discussed and then hypotheses are developed based on the relationships among them. Finally, correlation and regression analyses have been conducted and comments have been made on the findings.

\subsection{Aspects of Globalization}

While globalization provides a variety of benefits and certain "positive aspects" for enterprises, it also has "negative aspects" as it presents risks (threats). The basic issue of globalization in affecting domestic enterprises 
is that any other firm anywhere in the world may produce a cheaper or higher quality product or service without encountering any obstacles and put it on the market for customers to access. Having a challenging effect on competition in a number of ways, globalization evidently changes and transforms both market and organizational structures. We may list the reasons why globalization forces the market and enterprises to transform as follows (Erkan \& Eleren, 2001):

-Global liquidity of capital;

-Increased product diversification;

-Globalization of the market leads free circulation of goods to a higher extent;

-Customer expectations becoming more universal and this causes improvement of the product quality;

-Easier and cheaper transportation of raw materials, finished products and semi-finished products;

-Easy technological transfer; accelerated access to information;

-Increased efficiency and performance as a result of modernization of production techniques;

-Necessity of organizations to restructure into the form of multi-national and global enterprises as a result of increased foreign investments;

While the flow of financial capital has been liberalized and spread over different regions since the 1980s, a considerable real that "excess production" and "extreme competitive environment" were seen in the 1990s. As the globalization process has put enterprise in competition not only with its local rivals but also other competitors in other countries, competition has gained an international aspect. As a result of increased international production and trade worldwide, there is an opportunity for producing and selling new products constantly and participating in new markets, global production and supply chains along with the globalization of production (Aykaç, Parlak, \& Özdemir, 2008). Adaptation attempts to the rapid improvements in the production and distribution technologies create, on one hand, an increase in the investment costs, but on the other hand, they help firms be more effective and efficient (Yeşil, 2010). Beside efficiency concerns, excessive global competition creates pressure on the costs of the production and distribution inputs and production processes. Technological development in tangent with globalization provides companies with a new marketing opportunity called "electronic commerce". This new method allows operations such as production, promotion, sale, purchase, distribution and payment for goods and services to be performed via a network of computers, bringing a great number of opportunities to enterprises. In particular, the increased speed of technological change forces enterprises to adapt to innovation, change and transforming the market. Furthermore, enterprises are now required to implement fully, and in a timely fashion, the internal changes they need to make in order to adapt themselves to these technological changes.

The important factors therefore concerning the effects of globalization on enterprises include Intensity of Competition, New Opportunities, Speed of Technological Change and Cost Pressure.

\subsection{Hypotheses of the Relationship between the Globalization Effect and Operational Performance}

Operational performance may be expressed as the use of differentiated skills of the operational functions of the enterprise in relation to rivals, in order to gain competitive advantage (Swamidass \& Newell, 1987). Key factors in increasing operational performance are Cost, Quality, Flexibility and Delivery Speed. Various studies have been made on the relationship between environmental factors and operational process \& performance. Among them, the theoretical studies carried out by Swamidass and Newell have put forward that environmental dynamism has an important role in the relationship between the operational and general performance. The studies carried by Ward et al. have showed that globalization increases dynamism in the environment, obliges firms to differentiate and when correctly adapted to the conditions of globalization, operational processes can increase operational performance (Ward et al., 1995, Ward et al., 1996). Now we examine the effects of the intensity of competition, speed of technological change, cost pressure and new opportunities, which have been selected due to their significance as the sub-components of the globalization effect, on the operational performance.

\subsubsection{Effects of the Components of Globalization on Quality Performance}

According to Das et al. (2000), international competition together with quality practices increase customer satisfaction so this causes increase product quality and its performance, (Quality performance is a combination of customer perceptions about products and services' quality, decreasing number of product returns from buyers, defects, discards, reworks, etc.) and reduction of the price. Therefore where there is intense competition, 
performance is one of the most important tools. With the expectation that there is a regular relationship between perceived competiveness and quality performance, we develop the following hypothesis.

H1a: Perceived Intensity of Competition increases the quality performance.

Starting with the Japanese companies and affected by others have adapted technological innovation to their production processes and supported them with new management techniques in order to turn current opportunities to their advantages and/or gain new opportunities. Now these enterprises have competitiveness with respect to the factors of quality and low cost in the market. (Sayli, 2012). Those firms that try to utilize the new opportunities they observe should improve quality levels of their outputs. With the expectation that new opportunities will lead to increases in quality, we put forward the following hypothesis:

H1b: Observation of New Opportunities increases the quality of performance.

Technology and quality standards are improving continuously together. Technology along with conditions and requirements bring different dimensions to quality. Quality becomes a dynamic characteristic in its nature and develops and changes in line with consumer requirements. Only in this way can organizations adapt themselves to the changing and developing enterprise environments (Aytekin, 2003). With the expectation that the increase in the speed of technological change will cause constant improvement in quality, we propose the following hypothesis:

H1c: Achived Speed of the Technological Changes increases the quality performance.

Cost pressure forces firms to reorganize their manufacturing and distribution processes to be more efficient and productive. In order to increase productivity, companies should invests for new and efficient technology transfer and total quality management systems. They increase investments costs firstly, but then they decrease reworks, human related defects, rejections, customer complaints, compensations, etc. (Beaumont \& Schroder, 1997) leading to an apparent quality improvement. Therefore cost pressure felt by managers of the firm may lead to an increase in quality. With the expectation that the cost pressure will have a positive effect on quality, we put forward the following hypothesis:

H1d: Experienced Cost Pressure increases the quality of performance.

\subsubsection{Effects of the Globalization Components on Cost Reduction Performance}

The concept of cost leadership gained popularity in 1980s with Michael Porter who is the founder of the modern strategy and one of the world's most important thinkers on management and competitiveness. As to Porter, it is the ability of an organization to gain competitive superiority by the implementation of the lowest cost structure in the industry without any negligence of other similar important areas such as service and quality (Parker, 2000).

Fawcett-Closs have, in their study published in 1993, stated that the changes arising from economic globalization have created a great competitive pressure on industrial markets and, as a result, enterprises have had to produce and distribute low-cost products in order to compete. For this purpose, enterprises sometimes prefer locating their production in countries where the costs are low, giving products their final form in other countries and then launch them in the home country (Fawcett \& Closs, 1993). Furthermore, enterprises try to keep their costs at low levels by preferring high volume production (Turhan, 2006). Consequently, the increased competition generates considerable pressures on reduction of the costs. With the expectation that there is a positive relationship between perceived competitiveness and the significance given to cost reduction, we have proposed the following hypothesis:

H2a. Perceived Intensity of Competition increases the cost reduction performance.

In the context of the pulling tendency of demand and the pushing tendency of technology, technological innovations also have a great effect on the formation of new opportunities, equal to the effect of customer demand. In other words, the product and process innovations developed over the course of time have changed market conditions and, consequently, the tools used by enterprises in competing. For example, in the transition from the period of labor-intensive production with the demand exceeding the supply to a period where the supply and demand are equalized with costs becoming lower, the innovation of the moving assembly line innovation by Ford (process innovation) played a key role. As a result of this innovation, the problem of restricted production has started to disappear and enterprises have started to use cost superiority as a competitive tool (Sayli, 2012). In this context, with the expectation that the perceived new opportunities will reduce the costs for competitive advantage, we have developed the following hypothesis.

H2b. Observation of New Opportunities increase cost reduction performance. 
Rapid changes in technology allow development of the tools/instruments and processes necessary for production within a short time. For example, with the help of new production techniques, many industries have become able to perform mass production in an economical way, considering the diversity of products. Upon the integration of the microprocessor and computer technology, many products and services have differentiated on the basis of software. In many practices, incorporation of the software into the hardware has caused an increase of efficiency and, as a result, a dramatic reduction of the product costs (Bettis \& Hitt, 1995). Furthermore, acceleration of the processes also increases technological change. With the expectation that increased speed of technological change will cause a reduction in operational costs, we have put forwarded the following hypothesis:

H2c. Achieved Speed of Technological change increases cost reduction performance.

As to Hill, price is an important market-gaining criterion in many markets and particularly in the growth and maturity stages of the product life curve. As it is, the purpose of operational activities should be to provide necessary low costs in order to support sensitivity of the market to the price. When the product price is kept low to gain market share, the operational functions undertake the task of reducing the costs in order to protect the current profits or sustain profitability (Aytekin, 2003). In other words, cost pressure applies pressure in reducing operational costs. In this context, with the expectation that cost pressure will reduce operational costs, we have proposed the following hypothesis:

H2d. Experienced Cost Pressure increases cost reduction performance.

\subsubsection{Effects of the Globalization Components on Flexibility Performance}

Flexibility is the ability to adapt to the competitive environment. As the competition intensifies, firms may try to increase their flexibility to survive. Miller and Roth (1994) studied it under two different categories, namely design flexibility i.e. the ability to make design changes in a short time and/or to launch new products rapidly and volume flexibility i.e. the capability to respond to fluctuations in the demand. Sanchez (1995) also found a significant relation between competitive environment and flexibility. Therefore we have put forwarded the following hypothesis:

H3a. Perceived Intensity of Competition increases the flexibility performance.

Especially entrepreneurial firms pay more attention to seek market opportunities and try to adapt themselves to exploit the newly found ones. Alpkan et al. (2007) assert that market oriented firms trying to make use of new opportunities should improve their level of flexibility accordingly. With the expectation that the perception of new opportunities will therefore increase flexibility in the operational processes, we have developed the following hypothesis:

H3b. Observation of New Opportunities increase the flexibility performance.

According to Mohanty-Deshmukh (2000), operational flexibility is one of the most important operating tools which fight with the technological changes in the environment. The ease it provides for enterprises is the operational flexibility to switch from one product policy to another product policy when required. Flexible manufacturing systems and computer-assisted design and production may be given as an example for this strategic tool. Owners and managers perceiving the technological environment as a rapidly changing one spend more time and money to their ability to adapt. With the expectation that the increased speed of technological change will cause an increase in flexibility, we have put forward the following hypothesis:

\section{H3c. Achieved Speed of Technological Change increases flexibility performance.}

In general, increased flexibility in production is achieved through the use of high-cost multi-functional machines. If applied correctly, advanced production technologies reduce the cost of achieving production flexibility (Ward, et al., 1996). The time taken to launch a new product, the average product change process time and stock turnover are all related to the degree of flexibility. The role of the manufacturer is to keep developing these processes which are flexible and ensure low costs so as to cope with the product differences. (Doğan, 2008). The cost pressure also forces enterprises to act in this way. With the expectation that cost pressure will increase flexibility, we have proposed the following hypothesis:

H3d. Experienced Cost Pressure increases flexibility performance.

\subsubsection{Effects of the Components of Globalization on Delivery Speed Performance}

Greasly (1999) has expressed the delivery speed as the time range between the request by the customer for any product or service and the fulfillment of such requests. There are two important components in delivery performance, namely, speed and reliability. Quick shipment to the customer provides many competitive advantages and delivery speed is vitally important to many enterprises. Delivery reliability is the shipment of the 
products in the requested quantity on time (Stock, Greis, \& Kasarda, 1999). Increasing competition forces enterprises to increase delivery speed. With the expectation that an increase in perceived competitiveness will have positive effects on delivery speed, we have developed the following hypothesis.

H4a. Perceived Intensity of Competition increases the delivery speed performance.

In studies undertaken by Boyd ("Kaynak Bağımlllı̆̆ Teorisi”, www.angelfire.com/nt/zeus/yl/yl7.doc., 02. 05. 2011), as to the source dependability theory, external resources and information are parameters showing the degree of dependability of the enterprise in the environment. The firms encounter dependability at various levels. New opportunities appear as factors minimizing the dependability of the enterprises, leading to growth of the firms and in addition, increased performance. Enterprises becoming less dependable to the old certainties direct their efforts to new opportunities and try to improve their speed of delivery to gain competitive advantage. In other words new developments may provide creative destruction by changing the rules of the competitive game and by opening new windows of opportunities. If we cannot deliver solutions to exploit new opportunities in a speedy way, competitors may reap the fruits before we do. With the expectation that new opportunities will increase delivery speed, we have put forwarded the following hypothesis.

H4b. Observation of New Opportunities increases delivery speed performance.

As a result of rapid change in technology, with the integration of telecommunication and information technologies with operational processes, many industries have gained the ability to perform mass production economically by taking into consideration great product diversification, leading to short delivery time of the products. Furthermore, advancements in communication and technological developments in the transportation vehicles performing physical deliveries have also caused shorter product delivery times and increased reliability (Bettis \& Hitt, 1995). For this reason, with the expectation that an increased speed of technological change will cause improvement of delivery speed, we have proposed the following hypothesis.

H4c. Achieved Speed of Technological change increases delivery speed performance.

Under competitive pressures, according to Greasley (1999) costs management and delivery speed are related to each other, in such a way that cost reduction efforts do not only reduce costs but also they may shorten delivery time. Especially standardization and stock keeping operations to cut costs will also be useful in shortening delivery times. With the expectation that perceived cost pressure will increase delivery speed, we have developed the following hypothesis.

H4d. Experienced Cost Pressure increases delivery speed performance.

\subsection{Model}

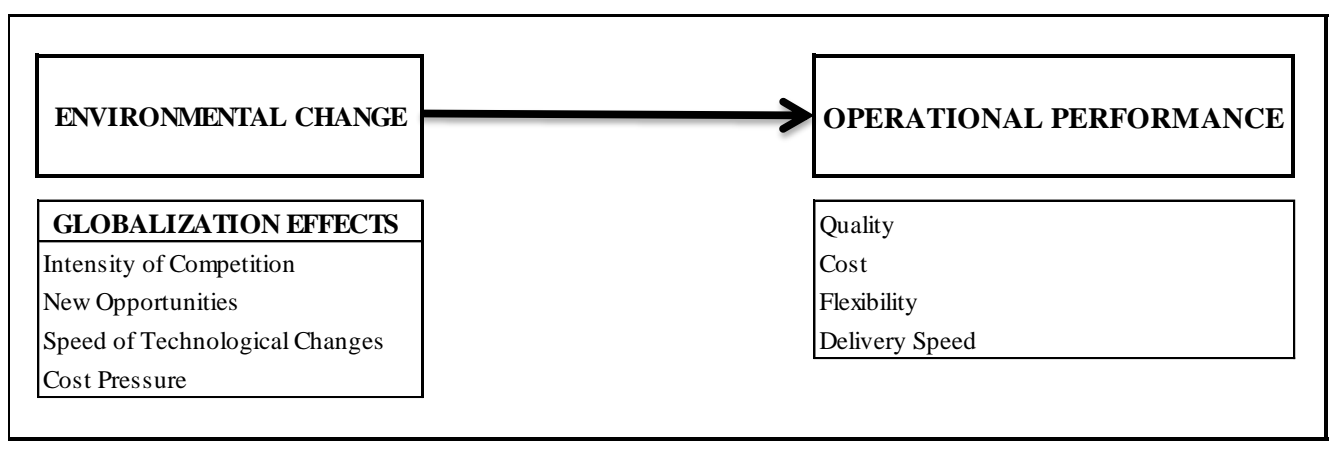

Figure 1. Research model

\section{Method}

\subsection{Methodology of the Study}

In order to test the model illustrated in the figure above and the hypotheses put forward, micro-and large-scale firms were sorted from 510 firms operating in the electric industry as per the data from the Istanbul Chamber of Commerce (I.T.O) and 751 firms as per the data from the Istanbul Chamber of Industry (I.S.O) and, as a result, 192 Small and Medium Scale firms were chosen as main mass (50 firms from I.T.O and 142 firms from I.S.O). We had access to 110 firms as a result of survey studies through actual visits by appointment, e-mail and telephone. Our study variables are measured by a questionaire formed by using different earlier studies'scales. 
Intensity of competition scale and speed of technological changes scale are developed based on the study of Doğan 2008; cost pressure scale taken from Badri, Davis, and Davis (2000); New Opportunities scale was self-developed i.e. developed by the authors of this article. Operational performance scale is also developed based on the study of Alpkan, Ceylan, and Aytekin (2002).

\subsection{Size/Structural Distribution Indicators of Sampling}

Individual SMEs in the Turkish electric industry constitute our unit of analysis, $40 \%$ of them engage with trading, $39.1 \%$ with both production and trading, and $14.5 \%$ with production activities. It was found that $60 \%$ of them have the legal status of a limited liability company, 26.4\% of Joint Stock Company and $10.9 \%$ of unlimited company. $67 \%$ were found to be small-scaled and 33\% medium-scaled. $28.1 \%$ of them have $11-20$ years of experience in business, $26.4 \%$ have 1-10 years of experience, $22.8 \%$ have $21-30$ years of experience and $15.4 \%$ have 31-40 years of experience.

\section{Results}

\subsection{Factor Analysis}

\subsubsection{Factor Analysis for Globalization Variables}

According to the results of the factor analysis made for the opportunities resulting from globalization, total variance extracted was calculated as $73.309 \%$ and two factors were produced, namely Speed of Technological Change and New Opportunities, whose items are given in Table 1. And according to the results of the factor analysis made for the threats resulting from globalization, total variance extracted was calculated as $66.349 \%$ and two factors were produced, namely Intensity of Competition and Cost Pressure, whose items are given in Table 2.

Table 1. Results of factor analyses for the opportunities resulting from the globalization variables

\begin{tabular}{lcc}
\hline \multicolumn{1}{c}{ DESCRIPTION } & NEW OPPORTUNITIES SPEED OF TECHNOLOGICAL CHANGE \\
\hline $\begin{array}{l}\text { Technological development speed of the production } \\
\text { processes in the industry has increased much }\end{array}$ & 0.832 \\
Thanks to the technological advancements in the industry, it \\
is possible to realize many new product ideas.
\end{tabular}

Note. Rotation Method: Varimax; Total Variance (\%): 73.309.

Table 2. Results of factor analyses for the threats resulting from the globalization variables

\begin{tabular}{|c|c|c|}
\hline \multirow{2}{*}{$\begin{array}{l}\text { DESCRIPTION } \\
\text { There a very fierce price competition among the companies in the sector. }\end{array}$} & \multicolumn{2}{|c|}{ INTENSITY OF COMPETITION COST PRESSURE } \\
\hline & 0.901 & \\
\hline Customer loyalty to the companies in the sector has weakened. & 0.829 & \\
\hline Competition level among the companies in the sector has increased much. & 0.799 & \\
\hline Lease costs have increased much & & 0.796 \\
\hline Transportation costs have increased much. & & 0.777 \\
\hline Power, water and town gas costs have increased much. & & 0.748 \\
\hline Raw material costs have increased much. & & 0.726 \\
\hline Labor costs have increased much. & & 0.712 \\
\hline Variance $(\%)$ & 29,548 & 36,861 \\
\hline
\end{tabular}

Note. Rotation Method: Varimax; Total Variance (\%): 66.409. 


\subsubsection{Results of the Factor Analysis for Operational Performance}

Total variance as stated according to the results of the factor analysis conducted for the Operational Performance variables was calculated as $68.414 \%$ and given to 4 factors as detailed in Table 3. They are Quality, Cost, Flexibility and Delivery Speed, respectively.

Table 3. Results of factor analysis for operational performance

\begin{tabular}{|c|c|c|c|c|}
\hline DESCRIPTION & QUALITY & COST & FLEXIBILITY & DELIVERY SPEED \\
\hline Number of product returns from the customer has reduced. & 0.822 & & & \\
\hline Quantity of waste, discards and reworks has reduced. & 0.800 & & & \\
\hline $\begin{array}{l}\text { Number of defective and irregular finished or intermediate } \\
\text { products has reduced }\end{array}$ & 0.777 & & & \\
\hline $\begin{array}{l}\text { Our product and service quality has increased in the eyes of the } \\
\text { customers. }\end{array}$ & 0.609 & & & \\
\hline Total costs in the production process have increased. & & 0.833 & & \\
\hline $\begin{array}{l}\text { Total costs in the internal and external logistic processes have } \\
\text { reduced. }\end{array}$ & & 0.791 & & \\
\hline Process costs have reduced. & & 0.746 & & \\
\hline Personnel efficiency has reduced. & & 0.617 & & \\
\hline $\begin{array}{l}\text { Replacement ability of the equipment assigned to each work } \\
\text { has increased depending on the changing work priorities. }\end{array}$ & & & 0.808 & \\
\hline $\begin{array}{l}\text { Ability of the personnel working at the manufacture to work at } \\
\text { various and different functions has improved. }\end{array}$ & & & 0.772 & \\
\hline $\begin{array}{l}\text { Flexibility to change the work priorities depending on the } \\
\text { orders has improved. }\end{array}$ & & & 0.749 & \\
\hline $\begin{array}{l}\text { Ability to use the existing equipment and personnel flexibly } \\
\text { for production of the non-standard products has improved. }\end{array}$ & & & 0.732 & \\
\hline $\begin{array}{l}\text { Ability to produced non-standard products according to } \\
\text { different customer orders has improved. }\end{array}$ & & & 0.600 & \\
\hline $\begin{array}{l}\text { Time between receipt of purchase order and delivery has } \\
\text { decreased. }\end{array}$ & & & & 0.839 \\
\hline Delivery speed of the finished products increased. & & & & 0.814 \\
\hline $\begin{array}{l}\text { Time between start of the production process and delivery has } \\
\text { decreased. }\end{array}$ & & & & 0.740 \\
\hline $\begin{array}{l}\text { Ability to keep the promises given previously for delivery has } \\
\text { improved. }\end{array}$ & & & & 0.739 \\
\hline Ability to deliver on just-in-time basis has improved. & & & & 0.726 \\
\hline Variance $(\%)$ & 15,274 & 13,630 & 19,613 & 19,897 \\
\hline
\end{tabular}

Note. Rotation Method: Varimax; Total Variance (\%): 68.414.

\subsection{Reliability Test}

As a result of calculation of Cronbach's Alpha internal consistency coefficients for all variables were above the value recognized in the literature (.700) (Nunnally, 1978) and are shown in Table 4 in detail. 
Table 4. Cronbach's Alpha values

\begin{tabular}{lcc}
\hline VARIABLES & NUMBER OF ITEMS & CRONBACH'S ALPHA \\
\hline Intensity of Competition & 3 & 0.804 \\
Speed of Technological Change & 3 & 0.861 \\
Cost Pressure & 5 & 0.828 \\
New Opportunities & 3 & 0.716 \\
Quality & 4 & 0.838 \\
Cost & 4 & 0.759 \\
Flexibility & 5 & 0.877 \\
Delivery Speed & 5 & 0.899 \\
\hline
\end{tabular}

\subsection{Means, Standard Deviations, Correlation Coefficients of Variables}

Means and standard deviations of all variables together with the results of the correlation analysis of the variables are shown in Table 5. We may say that there is a relation in positive or negative sense for each meaningful relation (at the level of $\mathrm{P}<0.01$ or $\mathrm{P}<0.05$ ) in the table. Looking at the table, relations can be seen between each Operational performance (Delivery Speed, Flexibility, Quality and Speed of Technological Change) and Globalization factors (Flexibility, Quality, New Opportunities and Cost Pressure and the Speed of Technological Change).

Table 5. Mean, standard deviation, correlation coefficients of variables

\begin{tabular}{|c|c|c|c|c|c|c|c|c|c|c|c|c|}
\hline \multicolumn{13}{|c|}{ Correlations } \\
\hline & & \multirow[t]{2}{*}{ Variables } & \multirow[t]{2}{*}{ Mean } & \multirow{2}{*}{$\begin{array}{c}\text { Std. } \\
\text { Deviation }\end{array}$} & \multicolumn{4}{|c|}{ Globalization } & \multicolumn{4}{|c|}{ Operational Performance } \\
\hline & & & & & 1 & 2 & 3 & 4 & 5 & 6 & 7 & 8 \\
\hline \multirow[t]{4}{*}{ Globalization } & 1 & Intensity of Competition & 4.1364 & .98334 & 1 & & & & & & & \\
\hline & 2 & $\begin{array}{l}\text { Speed of Technological } \\
\text { Change }\end{array}$ & 4.1455 & .94554 &, $566^{* *}$ & 1 & & & & & & \\
\hline & 3 & Cost Pressure & 3.7642 & .89150 &, $393 * *$ &, $505 * *$ & 1 & & & & & \\
\hline & 4 & New Opportunities & 3.4220 & 1.01495 & 0.145 &, $483 * *$ &, $301 * *$ & 1 & & & & \\
\hline \multirow{4}{*}{$\begin{array}{l}\text { Operational } \\
\text { Performance }\end{array}$} & 5 & Quality & 3.7848 & .89926 &, $218 *$ &, $376 * *$ &, $315 * *$ &, $317 * *$ & 1 & & & \\
\hline & 6 & Cost & 2.7833 & .89427 & 0.014 & 0.009 & -0.052 & 0.135 &, $284 * *$ & 1 & & \\
\hline & 7 & Flexibility & 3.5421 & .87163 & 0.125 &, $416^{* *}$ &, $401 * *$ &, $431 * *$ &, $467 * *$ &, $276^{* *}$ & 1 & \\
\hline & 8 & Delivery Speed & 3.8995 & .87994 &, $246 * *$ &, $504 * *$ &, $365 * *$ &, $417 * *$ &, $467 * *$ &, $264 * *$ &, $591 * *$ & 1 \\
\hline
\end{tabular}

\subsection{Testing Hypotheses}

Results of the regression analysis conducted to determine the effects of the Globalization Components on the Operational Performance Components are shown in the following tables.

Table 6. Effects of the globalization components on quality performance

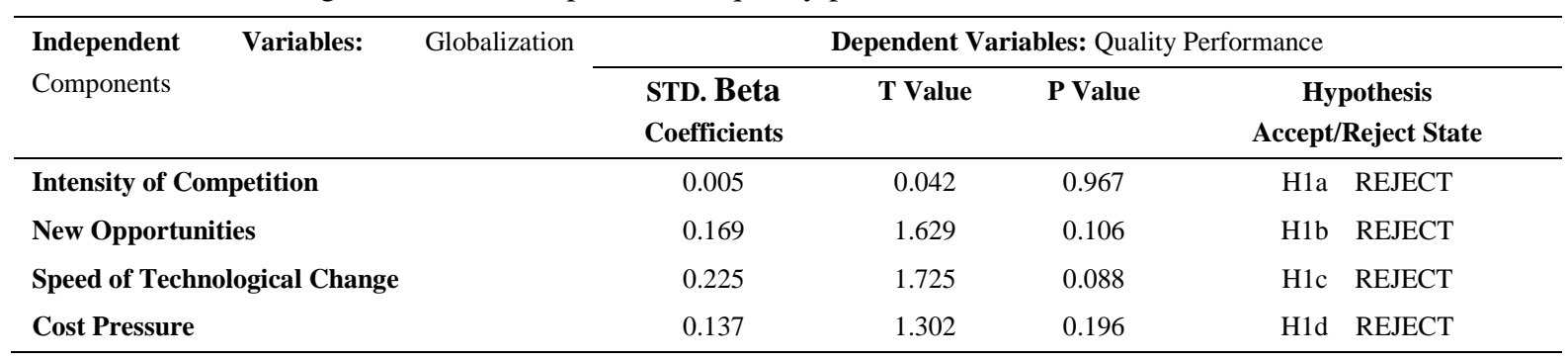

Note. $\mathrm{R}^{2}$ : .183; F: 5.750; P: .0000. 
Table 7. Effects of the globalization components on cost reduction performance

\begin{tabular}{|c|c|c|c|c|c|c|}
\hline \multirow{2}{*}{\multicolumn{2}{|c|}{$\begin{array}{l}\text { Independent } \\
\text { Components }\end{array}$}} & \multirow[t]{2}{*}{ Globalization } & \multicolumn{4}{|c|}{ Dependent Variables: Cost Reduction Performance } \\
\hline & & & $\begin{array}{l}\text { STD. Beta } \\
\text { Coefficients }\end{array}$ & T Value & P Value & $\begin{array}{c}\text { Hypothesis } \\
\text { Accept/Reject State }\end{array}$ \\
\hline \multicolumn{3}{|c|}{ Intensity of Competition } & 0.057 & 0.472 & 0.638 & H2a REJECT \\
\hline \multicolumn{3}{|c|}{ New Opportunities } & 0.189 & 1.671 & 0.098 & $\mathrm{H} 2 \mathrm{~b}$ REJECT \\
\hline \multicolumn{3}{|c|}{ Speed of Technological Change } & -0.060 & -0.422 & 0.674 & $\mathrm{H} 2 \mathrm{c}$ REJECT \\
\hline \multicolumn{3}{|l|}{ Cost Pressure } & -0.107 & -0.937 & 0.351 & H2d REJECT \\
\hline
\end{tabular}

Note. $\mathrm{R}^{2}$ : .032; F: .852; P: .496.

Table 8. Effects of the globalization components on flexibility performance

\begin{tabular}{|c|c|c|c|c|c|c|}
\hline \multirow{2}{*}{$\begin{array}{l}\text { Independent } \\
\text { Components }\end{array}$} & \multirow[t]{2}{*}{ Variables: } & \multirow[t]{2}{*}{ Globalization } & \multicolumn{4}{|c|}{ Dependent Variables: Flexibility Performance } \\
\hline & & & $\begin{array}{l}\text { STD. Beta } \\
\text { Coefficients }\end{array}$ & T Value & P Value & $\begin{array}{c}\text { Hypothesis } \\
\text { Accept/Reject State }\end{array}$ \\
\hline \multicolumn{3}{|c|}{ Intensity of Competition } & -0.158 & -1.496 & 0.138 & H3a REJECT \\
\hline \multicolumn{3}{|c|}{ New Opportunities } & 0.255 & 2.611 & 0.010 & $\mathrm{H} 3 \mathrm{~b}$ ACCEPT \\
\hline \multicolumn{3}{|c|}{ Speed of Technological Change } & 0.244 & 1.959 & 0.053 & $\mathrm{H} 3 \mathrm{c}$ REJECT \\
\hline \multicolumn{3}{|l|}{ Cost Pressure } & 0.270 & 2.740 & 0.007 & $\mathrm{H} 3 \mathrm{~d}$ ACCEPT \\
\hline
\end{tabular}

Note. $\mathrm{R}^{2}$ : .303; F: 10.853; P: .000.

Table 9. Effects of the globalization components on delivery speed performance

\begin{tabular}{|c|c|c|c|c|c|c|}
\hline \multirow{2}{*}{\multicolumn{2}{|c|}{$\begin{array}{l}\text { Independent } \\
\text { Components }\end{array}$}} & \multirow[t]{2}{*}{ Globalization } & \multicolumn{4}{|c|}{ Dependent Variables: Delivery Speed Performance } \\
\hline & & & $\begin{array}{l}\text { STD. Beta } \\
\text { Coefficients }\end{array}$ & T Value & P Value & $\begin{array}{c}\text { Hypothesis } \\
\text { Accept/Reject State }\end{array}$ \\
\hline \multicolumn{3}{|c|}{ Intensity of Competition } & -0.046 & -0.45 & 0.653 & H4a REJECT \\
\hline \multicolumn{3}{|c|}{ New Opportunities } & 0.208 & 2.171 & 0.032 & $\mathrm{H} 4 \mathrm{~b}$ ACCEPT \\
\hline \multicolumn{3}{|c|}{ Speed of Technological Change } & 0.366 & 3.042 & 0.003 & $\mathrm{H} 4 \mathrm{c}$ ACCEPT \\
\hline \multicolumn{3}{|l|}{ Cost Pressure } & 0.13 & 1.339 & 0.184 & H4d REJECT \\
\hline
\end{tabular}

Note. $\mathrm{R}^{2}$ :.307; F: 11.422; P: .000.

\section{Discussion}

In this section, the results of the analyses made in the previous sections will be evaluated by the hypotheses generated prior to the data collection and analyses and the results obtained will be interpreted. In Figure 2, we detail in summary the model where we portray the analytical results and interactions we detected.

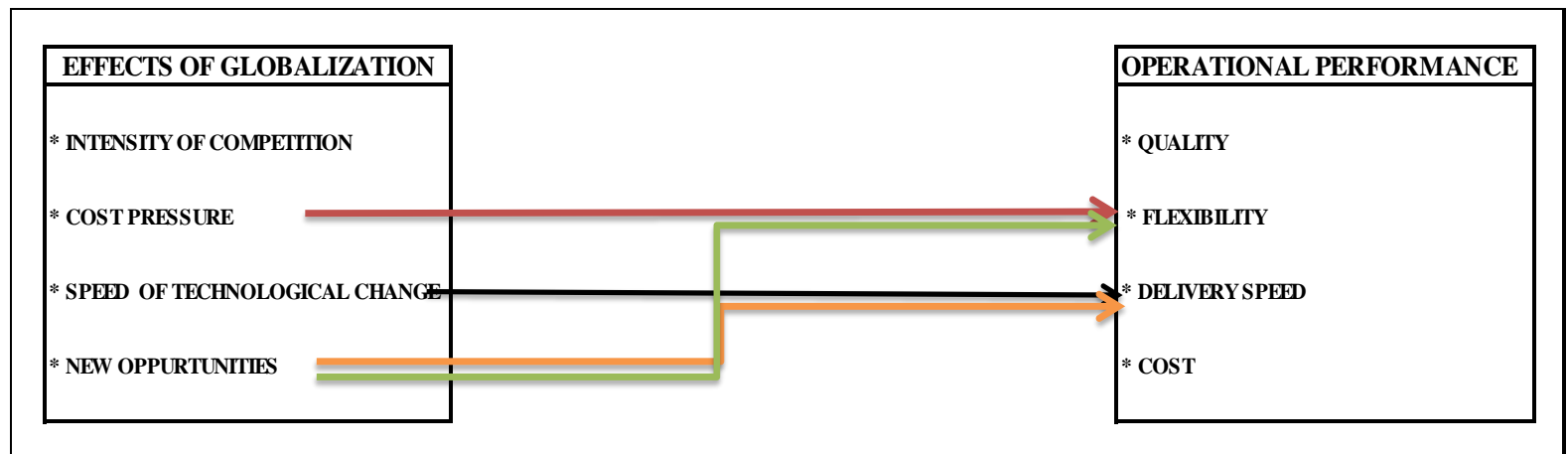

Figure 2. Model: results of the hypothesis test 
It has been determined that the opportunities resulting from globalization namely Speed of Technological Change and New Opportunities have a positive effect on the performance of Delivery Speed, a component of Operational Performance. In other words, we see that the increase in New Opportunities and Speed of Technological Change make Delivery Speed more important. Because the Speed of Technological Change in the electric industry is so high, SMEs owner/managers also get more and more sensitive towards these technological developments as soon as they occur.

The electric industry has become more integrated through the expansion of trade, development of logistic and technology, communication as well Globalization also constitutes new opportunities to exploit. Both are found to be the drivers of increased speed of delivery without which neither technological changes nor new opportunities can be turned into profit.

It is seen that the threats resulting from globalization namely Cost Pressure and New Opportunities have positively affected the performance of Flexibility, one of the Operational Performance components. Because of cost pressure, enterprises should manage their operational processes more flexibly. For instance, design of rotary switches is done according to the specific customer orders; without flexible production processes production of orders would be very expensive. Therefore owners and managers feel themselves obliged to increase their firm's flexibility to survive under cost pressure.

As for the effects of new opportunities, in this industry, generally operational processes are too short and, new products are being produced in a very short period of time and it causes changing product types very often. If not; flexible firms cannot adapt to these changes rapidly. Automatically this brings to new opportunities and enterprises get benefit them by increasing their flexibility.

Production, distribution, and supply chains in electric industry have become more integrated globally as they seem other industries. Organizations in electric industry operate in a production and trading environment with high competition due to the elimination of the protectionist approach. Such a highly competitive environment affects the enterprises on the scale of SME the most. In order to change this situation to a positive state of affairs, at least to a small extent, the organizations should attempt to gain competitive advantage. For this reason, executives should examine internal and external settings and develop strategies and continuously update and adapt their organizational structures, operational and other functional processes to ongoing changes and developments in a timely fashion.

\section{References}

Alpkan, L., Ceylan, A., \& Aytekin, M. (2002). Relations among environmental factors, manufacturing strategies and performance: A study of manufacturing firms in Gebze/Turkey. $2^{\text {nd }}$. International Conference on Responsive Manufacturing (pp. 435-441).

Aykaç, M., Parlak, Z., \& Özdemir, S. (2008). Küreselleşme Sürecinde Rekabet Gücünün Artırllması ve Türkiye'de KOBI'ler. İTO, No: 2008-24, İstanbul/Turkey, p. 183.

Aytekin, M. (2003). Imalat ve rekabet stratejileri arasindaki ilişki ve performansa etkileri (pp. 33-38). Doctoral dissertation, G.Y.T.E., Gebze/Turkey.

Badri, M. A., Davis, D., \& Davis, D. (2000). Operations strategy, environmental, uncertainty and performance: A path analytic model of industries in developing countries. Omega, 28, 155-173. http://dx.doi.org/10.1016/S0305-0483(99)00041-9

Beaumont, N. B., \& Schroder, R. M. (1997). Technology, manufacturing performance and business performance $\begin{array}{lllll}\text { amongst Australian } & \text { 297-307. }\end{array}$ http://dx.doi.org/10.1016/S0166-4972(97)00011-4

Bettis, R. A., \& Hitt, M. A. (1995). The new competitive landscape. Strategic Management Journal, 16, 7-19. http://dx.doi.org/10.1002/smj.4250160915

Das, A., Handfield, R. B., Calantone, R. J., \& Ghosh, S. (2000). A contingent view of quality management-The impact of international competition on quality. Decision Sciences, 31, 649-690. http://dx.doi.org/10.1111/j.1540-5915.2000.tb00938.x

Doğan, T. (2008). Strateji tipleri ve stratejik yönetim süreçlerinin firma performansına etkileri. Doctoral dissertation, G.Y.T.E., Gebze/Turkey.

Erkan, M., \& Eleren, A. (2001). Küreselleşme sürecinde kobi'lerin yeniden yapılandırllması ve bir model önerisi, Orta Anadolu Kongresi Raporu, Nevşehir, 18-21 October 2001, p. 161. 
Fawcett, S. E., \& Closs, D. J. (1993). Coordinated global manufacturing: The logistics/manufacturing interaction and firm performance. Journal of Business Logistics, 14(1), 1-25.

Greasley, A. (1999). Operations Management in Business. Stanley Thornes Ltd., UK.

İraz, R. (2005). Küresel rekabet ortamında küçük ve orta büyüklükteki işletmelerin ulusal sosyo-ekomomik sisteme katkıları açısından değerlendirmesi (pp. 223-236). Retrieved from http://www.sosyalbil.selcuk.edu.tr/sos_mak/makaleler/R\% C 4\%B1fat\%20\%C4\%B0RAZ/223-236.pdf

İzmirlioğlu, A. (2000). Küreselleşme özel ihtisas komisyonu raporu. Sekizinci Beş Yıllık Kalkınma Planı, DPT: 2544, ÖİK: 560, Ankara/Turkey, 4. Retrieved from http://iii ekutup.dpt.gov.tr/dunya/oik560.pdf

Kaynak, B. T. (2011). Retrieved from http://www.angelfire.com/nt/zeus/yl/yl7.doc

Miller, J. G., \& Roth, A. V. (1994). A taxonomy of manufacturing strategies. Management Science, 40(3), 285-304. http://dx.doi.org/10.1287/mnsc.40.3.285

Monathy, R. P., \& Deshmukh, S. G. (2000). Evaluating manufacturing strategy for a learning organization: A case. International Journal of Operations \& Production Management, 19(3), 308-327. http://dx.doi.org/10.1108/01443579910249732

Nunnally, J. C. (1978). Psychometric theory. New York, NY: McGraw- Hill.

Parker, A. R. (2000). Impact on the organizational performance of the strategy-Technology policy interaction. Journal of Business Research, 47(1), 56. http://dx.doi.org/10.1016/S0148-2963(98)00051-4

Sanchez, R. (1995). Strategic flexibility in product competition. Strategic Management Journal, 16, 135-159. http://dx.doi.org/10.1002/smj.4250160921

Sayl1, H. A. K. Ü. (2012). Retrieved from http://www.2.aku.edu.tr/ halilsayli/sayfalar/yenilik.doc

Stock, G. N., Greis, N. P., \& Kasarda, J. D. (1999). Logistics, strategy and structure: A conceptual framework. International Journal of Physical Distribution \& Logistics Management, 29(4), 224-239. http://dx.doi.org/10.1108/09600039910273948

Swamidass, P. M., \& Newell, W. T. (1987). Manufacturing strategy, environmental uncertainty and performance: A path analytic model. Management Science, 33, 509-524. http://dx.doi.org/10.1287/mnsc.33.4.509

Turhan, N. (2006). Imalat stratejisinin işletme performansina etkisinin incelenmesi tekstil sektörü uygulaması (Master's Thesis). Karadeniz Teknik Üniversitesi Sosyal Bilimler Enstitiüsü, June, $30^{\text {th }}$.

Ward, P. T., Bickford, D. J., \& Leong, G. K. (1996). Configurations of manufacturing strategy, business strategy: Environment and structure. Journal of Management, 22(4). http://dx.doi.org/10.1177/014920639602200404

Ward, P. T., Duray, R., Leong, G. K., \& Sum, C. (1995). Business environment, operations strategy and performance: An empirical stud of Singapore manufacturers. Journal of Operations Management, 21(7). http://dx.doi.org/10.1016/0272-6963(95)00021-J

Yeşil, S. (2010). Küreselleşme ve işletmelerin küreselleşme süreçleri: Karşıllaşılan firsatlar ve tehditler. Ekonomik ve Sosyal Araştırmalar Dergisi, 6(1), 22-72.

\section{Copyrights}

Copyright for this article is retained by the author(s), with first publication rights granted to the journal.

This is an open-access article distributed under the terms and conditions of the Creative Commons Attribution license (http://creativecommons.org/licenses/by/3.0/). 